\title{
Moving health promotion communities online: a review of the literature
}

\author{
Naomi Sunderland, Jenine Beekhuyzen, Elizabeth Kendall \& Malcolm Wolski
}

Abstract

There is a need to enhance the effectiveness and reach of complex health promotion initiatives by providing opportunities for diverse health promotion practitioners and others to interact in online settings. This paper reviews the existing literature on how to take health promotion communities and networks into online settings. A scoping review of relevant bodies of literature and empirical evidence was undertaken to provide an interpretive synthesis of existing knowledge on the topic. Sixteen studies were identified between 1986 and 2007. Relatively little research has been conducted on the process of taking existing offline communities and networks into online settings. However, more research has focused on offline (i.e. not mediated via computer networks); 'virtual' (purely online with no offline interpersonal contact); and 'multiplex' communities (i.e. those that interact across both online and offline settings). Results are summarised under three themes: characteristics of communities in online and offline settings; issues in moving offline communities online, and designing online communities to match community needs.

Existing health promotion initiatives can benefit from online platforms that promote community building and knowledge sharing. Online ehealth promotion settings and communities can successfully integrate with existing offline settings and communities to form 'multiplex' communities (i.e. communities that operate fluently across both online and offline settings).

\section{Keywords:}

Health Promotion; Information Networks; Community Health Networks; Online Systems

Supplementary Term:

Multiplex Communities

Introduction

More than two and a half decades ago, the Ottawa Charter on Health Promotion (World Health Organization [WHO] 1986) highlighted the importance of the 'social determinants of health' (SDOH) and advocated a focus on the creation of health rather than the avoidance of disease. As the Charter stated, 'health is created and lived by people within settings of their everyday life; where they learn, work, play and love' (WHO 1986: 4). The Charter advocated a broader understanding of the way that social contexts promote or inhibit health and wellbeing. Significantly, the Charter also reframed access to positive SDOH as a key determinant of health equity between people who were able to significantly influence their own SDOH (e.g. where they lived), and people who could not. Taking these core elements of the Charter into account, the WHO defined health promotion as the 'process of enabling people to increase control over their health and its determinants, and thereby improve their health' (WHO 1997: 10). Hence the range and scope of who and what can be considered to be 'health practitioners', 'health services', and 'health information' is significantly expanded within health promotion approaches. Indeed, the 'health promotion' workforce that may contribute to and access 'health 
information' can include anyone from economic and social policy makers and urban planners to community nurses and teachers.

While e-health providers have responded to international understandings of health inequality in productive ways, such as providing online (via the Internet) health services to disadvantaged remote communities, they have not yet developed systematic ways of supporting complex health promotion initiatives that seek to address deep inequalities associated with the SDOH. Rather, the bulk of existing e-health activity has mirrored the existing health service system by providing individuals with health services online (Evers 2006; Fry \& Neff 2009; Hardiker \& Grant 2011; Skinner, Maley \& Norman 2006). Although these online health services respond to significant health needs in the community, they do not deliver solutions to complex place-based health determinants. Given that complex health promotion is often conducted across multiple sectors (e.g. communities, non-government organisations, and multiple levels of government) and large geographic areas, there is a great need for Health Information Managers and others to develop online platforms that can supplement and support offline activities.

This paper provides an important first step in supporting complex 'offline' health promotion initiatives (those conducted primarily in face-to-face and other non-Internet related settings) by reviewing the existing knowledge on how to take existing health promotion communities and networks into online settings.

\section{Method}

We conducted a 'scoping' (Booth, Papaioannou \& Sutton 2012: 83) literature review during February-August 2011 to gather evidence to design an online platform to support an existing offline place-based health promotion initiative in Logan-Beaudesert, QLD. The literature review answered the following question: what are the key concepts and conditions for successfully moving an of fline health promotion community online? We did not apply any temporal restrictions to the literature review (i.e. articles published within certain years); however, we expected that references to health promotion overall would not extend further back than the Ottawa Charter of 1986. Articles were included or excluded based on the retriever's interpretation of their relevance to the research question.

The authors initially searched for any full-text-online peer reviewed journal articles that specifically documented the process of taking existing offline initiatives or health promotion networks into online settings using the keywords: online-offline communities, health promotion, online health promotion, and online health promotion networks. We were not concerned with journal ratings at this stage of the research. We instead focused on identifying if there was any existing literature that documented the shift we were trying to make with our local place-based health promotion initiative. We could find no available literature that documented this shift, which further signified the degree to which complex health promotion initiatives are currently under-supported by online solutions. We then recruited a senior research assistant (SRA) with a strong disciplinary background in information technology and online communities to retrieve and interpret all relevant peer-reviewed literature that related to our review. The SRA first searched highly-ranked and esteemed information science journals, including Management Information Systems Quarterly (impact factor 4.447) and the J ournal of ComputerMediated Communication (impact factor 3.64) using the keywords: online/ virtual communities; learning communities; health promotion; and offline communities. The SRA then widened the search to Google Scholar to identify the most highly cited articles that included the same keywords (i.e. online/ virtual communities; learning communities; health promotion; and offline communities). The most relevant articles cited by these articles/ authors were also then retrieved and reviewed.

The SRA's search affirmed that there were no available articles that specifically related to health promotion networks and communities operating in online settings. While there was ample discussion of online communities in general (i.e. those where participants only engage with one another in online settings), the SRA's search produced relatively little literature that could provide insights on how to take existing offline networks into online settings. Based on the theoretical framework of our ongoing Australian Research Council (ARC) funded research on collaborative learning in place- 
based health promotion networks (Kendall et al. 2010-2012) ${ }^{1}$, we then resolved to retrieve any articles relating to processes for creating and sustaining online communities of practice and transformative learning communities which we argue have common theoretical foundations and processes to complex health promotion initiatives. The SRA conducted these additional searches and added the resulting articles for review and interpretation.

The relevant articles were then grouped and analysed based on their topic (e.g. of fline/ online communities, membership, participation, contributions), their theoretical perspective (e.g. transformative learning theory, diffusion of innovation), the nature of the research (e.g. conceptual/ empirical), the target audience of the community (e.g. place-based, young people) and community design elements conducive to participation or contribution, including the motivations and barriers. We then considered these in terms of the documented educational, leadership and health learning communities in the literature. Following the SRA's presentation of findings, the lead author then supplemented the SRA's existing literature searches by retrieving and interpreting the most highly cited and relevant available literature that included the term 'e-health promotion'. The resulting collection of articles for review were drawn from a mix of Australian and international journals across the fields of health, education, information systems, sociology and management. See Table 2 and the reference list for a summary of key research cited in this paper.

\section{Results}

The aim of our literature review was to identify existing evidence to guide the development of an online platform to support complex offline health promotion initiatives. We did not find any literature that exactly matched this requirement. In lieu of literature recommendations relating directly to establishing online settings to support health promotion initiatives, we distilled three core themes in the literature that can be used to inform the design of complex 'multiplex' health promotion initiatives. Multiplex communities are those that are able to operate fluently across both online and offline settings. Sixteen articles were subsequently included, which were published between 1986 and 2007 (Table 2). Themes covered in these 16 articles include: (a) characteristics of communities in online and offline settings; (b) issues in moving of fline communities online; and (c) designing online communities to match community needs.

\section{Characteristics of communities in online and offline settings}

In their seminal article on virtual communities, McMillan and Chavis (1986: 9) defined a sense of community as 'a feeling that members have of belonging, a feeling that members matter to one another and to the group, and a shared faith that members' needs will be met through their commitment to be together'. McMillan and Chavis' (1986) theory (and instrument) is one of the most broadly validated and widely utilised in the psychological literature. They argued that a community: provides a feeling of belonging and relatedness; provides a sense of mattering, of making a difference to a group and of the group mattering to its members; provides a feeling that members' needs will be met by the resources received through their membership in the group; makes members feel rewarded in some way for their participation in the community; and has shared emotional connections such as common history, common places, time together, and similar experiences.

Building upon the work from McMillan and Chavis, Whittaker, Isaacs and O'Day (1997) identified the following core attributes of online communities: members have a shared goal, interest, need, or activity that provides the primary reason for belonging to the community; members engage in repeated, active participation; often intense interactions, strong emotional ties, and shared activities occur among participants; members have access to shared resources, and policies determine the access to those resources; there is reciprocity of information, support and services among members is important; and there is a shared context of social conventions, language and protocol. Although the need for repeated, active participation and reciprocity are controversial, there 
is empirical evidence that these attributes are vital for the sustainability of online communities (Beekhuyzen \& von Hellens 2009). Others agreed that these elements are essential, and that without this repeated engagement there is no community (Preece 2000).

In the anthropological literature on online communities, Wilson and Peterson's (2002) extensive review also identified a missing link between the historically constituted sociocultural practices within and outside of mediated communication and the language practices, social interactions, and ideologies of technology that emerge from new information and communication technologies. Wilson and Peterson (2002) also suggested that one way to situate computing and Internet practice is to compare them with previously existing (before the Internet) media and communication technologies, considering how social interactions were conducted before the advent of digital technologies.

\section{Issues in moving offline communities online}

Researchers from many disciplines have identified strong potential for community building in online settings. However, little evidence exists about how existing offline communities can be taken online (Brown, Broderick \& Lee 2007). The bulk of existing literature focuses on the reverse: that is, how offline connections can strengthen communities that begin in online environments. Nevertheless, important conclusions from related literature can be extended to inform the process of taking an existing offline place-based initiative online. In their study of the Netville residential networked community for example, Hampton and Wellman (2000) found that relationships are rarely maintained through computer-mediated communication alone, but are sustained through a combination of online and offline interactions. Based on her study of the Queer Sisters bulletin board, Nip (2004) argued that the appearance of new online communities may actually strengthen the offline geographic communities, but only if the online communities bear the same goals and norms as the offline communities.

Using a social network theory approach in their longitudinal study of the Blacksburg Electronic Village, Kavanaugh and colleagues (2005) also found that Internet use can strengthen social contact, community engagement and attachment. However, Kavanaugh et al. (2005) presented further evidence that Internet use mainly strengthens social contacts, community engagement and attachment for people with relatively high levels of education, extroversion, sense of community belonging, community collective efficacy, group memberships, activism, and social use of the Internet. This finding that Internet use strengthens ties for people who are already relatively well connected highlighted concerns about the impact of computer networking on people with lower levels of education, extroversion, efficacy, and community belonging who may become further isolated when activities are conducted primarily online. Therefore, it is possible that moving health promotion communities online would exacerbate existing entrenched disadvantage by privileging those who are already likely to connect with others and ignoring those who are less likely to connect.

Irrespective of this concern, there is some evidence to suggest that once an offline community is functioning, it can significantly influence online interactions. Offline community rules and roles migrate naturally into the online community (MaloneyKrichmar \& Preece 2003). Kavanaugh et al. (2005) also argued that the crossover between the offline and online 'worlds' of the social network members will have important implications for other aspects of online behaviour, such as governance rules, people's roles, and norms of reciprocity. Some researchers have studied these social codes purely in an online community environment (Beekhuyzen, von Hellens \& Nielsen 2011) but the translation between environments is relatively under-researched.

\section{Designing online communities to match community needs}

Designing the right environment for online communities is a complex task that has implications for designers, facilitators and participants (Ryman et al. 2009). To address this complexity, Preece and co-authors proposed a community-centred approach to developing online communities (Preece 2000; Preece, Abras \& Maloney-Krichmar 2004). Preece et al.'s approach is similar to that of user-centred design (Astbrink \& Beekhuyzen 2003; Buhler 2000; Mao et al. 2005; Vredenburg, Isensee \& Righi 2002), a philosophy that puts 
the user (or community in this case) at the centre of the design process. Preece (2000) proposed that members of the community should work with developers to build the community from the beginning. As security and trust are particularly important to health communities (Preece 2000), it is important to consult community members as early as possible in the development process. Preece's (2000) framework for community-centred development of online communities (Table 1) suggests design strategies for system developers to build into the community the ability for people to interact and perform their tasks intuitively and easily. Table 1 presents a summary of Preece's recommended phases of community centred design that centre around three main groups of tasks: (i) assessing community needs and analysing user tasks; (ii) selecting technology and planning sociability; and (iii) designing, implementing, and testing prototypes. Each phase includes a list of activities, and the tasks required in each stage of designing and developing the community.

Table 1: Community-Centred Design Framework (source: Preece, J 2000, Online communities: Designing usability, supporting sociability, J ohn Wiley \& Sons Ltd, Chichester)

\begin{tabular}{|c|c|c|}
\hline \multicolumn{3}{|c|}{ Assessing community needs and analysing user tasks } \\
\hline 1.1 & $\begin{array}{l}\text { Find out who the users will be } \\
\text { and what they will expect: }\end{array}$ & $\begin{array}{l}\text { - Homogenous group? Age, gender, culture, knowledge of the topic, personalities. } \\
\text { Level of experience using the Internet and participating in other online } \\
\text { communities. }\end{array}$ \\
\hline 1.2 & $\begin{array}{l}\text { Clearly identify the main } \\
\text { purpose of the community: }\end{array}$ & $\begin{array}{l}\text { - Web-based infrastructure designed for using, sharing and expanding health and } \\
\text { related information and research evidence that supports a place-based social } \\
\text { and environmental determinants approach to health and well-being (Schulz and } \\
\text { Northridge 2004). } \\
\text { To provide the necessary platform to share valuable intellectual property } \\
\text { between general public, service providers and policy makers. The system } \\
\text { consists of public and private web domains which control access to various } \\
\text { modules including a health decision support system (based on a geospatial health } \\
\text { data), predictive modelling data for at-risk patients, a service directory, online } \\
\text { learning programs, public surveys and social and professional networking tools. } \\
\text { Such diverse resources will be used to inform local policy, development, service } \\
\text { planning and models of health care delivery. }\end{array}$ \\
\hline 1.3 & $\begin{array}{l}\text { Identify the main activities the } \\
\text { online community will engage } \\
\text { in:Analyse how tasks inherent } \\
\text { to the various activities will be } \\
\text { performed: }\end{array}$ & $\begin{array}{l}\text { Example tasks: } \\
\text { - Information dissemination - sending messages, announcements, pointers to URLs, } \\
\text { articles etc. Primarily unidirectional - posting is supervised by a central person. } \\
\text { - Information exchange - everyone can send and request information, e.g. } \\
\text { discussion groups, peer-help. } \\
\text { - } \quad \text { Discussion - discuss and comment on each other's ideas. } \\
\text { - Support - members exchanging information about problems and providing } \\
\text { empathy and sympathy for each other. } \\
\text { - Entertainment - participants playing games or circulating jokes. }\end{array}$ \\
\hline 1.4 & $\begin{array}{l}\text { Identify tasks and norms } \\
\text { including: }\end{array}$ & $\begin{array}{l}\text { - J oining and leaving the community (formal registration?). } \\
\text { - } \quad \text { Receiving and reading messages. } \\
\text { - } \quad \text { Composing and sending messages. } \\
\text { - } \quad \text { Consulting additional sources, such as web pages and FAQ lists. }\end{array}$ \\
\hline \multicolumn{2}{|c|}{ Stage Outcomes: } & $\begin{array}{l}\text { - The key needs of the community. } \\
\text { - The tasks that will satisfy these needs. } \\
\text { - } \quad \text { Demography of population. } \\
\text { - User Internet experience level. } \\
\text { - Technical constraints. }\end{array}$ \\
\hline 2 & \multicolumn{2}{|c|}{ Selecting technology and planning sociability } \\
\hline 2.1 & Software selection and usability: & $\begin{array}{l}\text { - Build in-house, customized from available components, use a public webspace } \\
\text { like geocities. com? } \\
\text { - Consider costs, technical skills, time, host, technical constraints, usability. }\end{array}$ \\
\hline 2.2 & Web-site design: & - Is it conceptually appropriate? \\
\hline
\end{tabular}




\begin{tabular}{|c|c|c|}
\hline 2.3 & Social planning: & $\begin{array}{l}\text { - } \quad \text { Closed community with registration process? } \\
\text { - } \quad \text { Mediator needed or other roles? } \\
\text { - } \quad \text { Disclaimers needed? } \\
\text { - } \quad \text { How to support social interaction? }\end{array}$ \\
\hline \multicolumn{2}{|c|}{ Stage Outcomes: } & $\begin{array}{l}\text { - Identification of software with appropriate functionality and good usability. } \\
\text { - } \quad \text { Identification of main sociability issues. }\end{array}$ \\
\hline \multicolumn{3}{|c|}{ Designing, implementing, and testing prototypes } \\
\hline 3.1 & $\begin{array}{l}\text { Develop prototypes and } \\
\text { scenarios - they are useful and } \\
\text { enable developers to: }\end{array}$ & $\begin{array}{l}\text { - Verify that they understand the community's purpose and needs. } \\
\text { - } \quad \text { Explore different design ideas. } \\
\text { test their designs and policies by involving users and experts in reviews and } \\
\text { through more rigorous usability testing techniques. } \\
\text { - Understand different situations in which the community may be used, and by } \\
\text { different user groups (scenarios). }\end{array}$ \\
\hline 3.2 & Testing: & $\begin{array}{l}\text { - Navigation structure, errors in instructions, inconsistent terminology, annoying } \\
\text { graphics, poor aesthetic design. }\end{array}$ \\
\hline 3.3 & General aims from this stage: & $\begin{array}{l}\text { - Evaluate the design by testing its usability and sociability through successive } \\
\text { iterations. } \\
\text { - Involve as many typical users from the community as possible. } \\
\text { - Develop scenarios in which users role-play typical activities so that they and the } \\
\text { developers understand the community's needs. }\end{array}$ \\
\hline \multicolumn{2}{|c|}{ Stage Outcomes: } & $\begin{array}{l}\text { - } \quad \text { Reports and recommendations - after each cycle of testing. } \\
\text { - } \quad \text { Software with good usability and sociability. } \\
\text { - } \quad \text { committee group of community members. }\end{array}$ \\
\hline \multicolumn{3}{|c|}{$4 \quad$ Refining and tuning sociability and usability } \\
\hline 4.1 & Fine tuning before launch: & - $\quad$ Obtain feedback from user communities. \\
\hline \multicolumn{2}{|c|}{ Stage Outcomes: } & $\begin{array}{l}\text { - A list of small usability problems that need fixing. } \\
\text { A list of spelling mistakes and inconsistencies in content and instructions that } \\
\text { need fixing. }\end{array}$ \\
\hline \multicolumn{3}{|r|}{ e community } \\
\hline & Welcoming (short-term): & $\begin{array}{l}\text { - } \quad \text { Mailing lists, linking to related sites, advertising. } \\
\text { - } \quad \text { Seeding the community with people who give it character. }\end{array}$ \\
\hline & $\begin{array}{l}\text { Nurture and support the } \\
\text { community (long-term): }\end{array}$ & $\begin{array}{l}\text { - } \quad \text { Moderators needing advice. } \\
\text { - } \quad \text { Clarifying policies. } \\
\text { - } \quad \text { Moderating conversations and members communications. }\end{array}$ \\
\hline \multicolumn{2}{|c|}{ Stage Outcomes: } & $\begin{array}{l}\text { A plan to see the community with people who will encourage its development } \\
\text { and attract others. } \\
\text { - A plan to carefully observe the community during the first six months of } \\
\text { existence and solve problems that occur. } \\
\text { - A long-term support plant for the community's long-term governance. }\end{array}$ \\
\hline
\end{tabular}

According to Preece (2000), online communities, like physical communities, develop in organic ways and are shaped by leaders, managers, and members. She likened the process of developing online communities to that of town planning where infrastructures need to be built (such as roads, public spaces, shopping facilities, residential housing, recreational spaces), and maj or services need to be developed (such as electricity, gas, telephone lines). Thus, online communities need to undertake the same processes of consultation and engagement with their 'customers' to ensure successful implementation of infrastructure. Similarly, Koh et al. (2007) argued that migrating of fline communities into online communities has the potential to greatly improve the efficiency of the community and its ability to support the sharing of critical information and knowledge in a timely fashion. However, system developers face important considerations in designing the best methods of communication among members, creating incentives to encourage motivation and participation, affording leadership opportunities, and keeping up with advances in technology.

Sessions' (2010) analysis of over eight years of user activity from a large, active online physically-dispersed community revealed that developing multiplex relation- 
ships - relationships that are maintained both online and offline - enhanced attendee's engagement with the online community as a whole. Session (2010) found that ties with non-attendees in online environments often dissolved over time because those who met offline tended to favour interaction with other (offline) attendees. Therefore, multiplex relationships are encouraged where possible. Online communities may find themselves highly vulnerable if social connections are not maintained offline.

Preece's (2000) research is reinforced in Wilson and Peterson's (2002) extensive review in which they argued that the study of online practices involves bringing research back from cyberspace and virtual reality into geographical social spaces to address a variety of issues, such as the ways in which new participants are socialised into online practices. It is important to consider how identities are negotiated, reproduced and indexed in online interactions, and how Internet and computing practices are becoming normalised or institutionalised in a variety of contexts. Koh et al. (2007) also argue in favour of multiplex communities believing that community developers can explore integrated ways to strengthen the social identity of their community's members through linking offline meetings to online activities (Koh et al. 2007). One such way to link offline with online is to provide access to the online world through publicly accessible community locations (see Hitnet - the Health Interactive Technology Network in North Queensland, Australia [http:/ / www. hitnet.com.au/ ] as an example), such as public libraries, municipal buildings or even street kiosks (Kavanaugh et al. 2005).

\section{Technological facilitators of multiplex communities}

Ma and Agarwal (2007) examined the role of technological infrastructure in shaping participant contributions online and found that participants' online identity plays a vital role in knowledge contributions. Ma and Agarwal's (2007) research attempted to bridge the gap between research and practice by elaborating on the mechanisms by which community features influence online knowledge-sharing behaviour. They found that when community members perceived a community as being useful to them, they were more likely to actively participate. Koh and colleagues (2007) also suggest that the social identity of the virtual community can be strengthened through the use of avatars and other visual cues like multimedia and videoconferencing. They found that online community members find it helpful to remember the physical appearance of other members or be able to match their real names with online nicknames when meeting in cyberspace. Koh et al. (2007) suggested that collecting, displaying and updating content regularly is critical for encouraging activity among community members. They also recommended a peer-evaluation system for posted materials that will filter out redundant and obsolete postings, and a reward system for valuable postings. Other features such as a rating system and user profiles may also be helpful in motivating members to participate.

Several other important attributes of social technology that could encourage the participation of motivated individuals were identified in a review of online health groups in the literature (Walther et al. 2005). These attributes included:

- Interactivity - tailoring content to users, increasing engagement in decision making, improving learning, increasing attractiveness, enhancing the influence of online services

- Presence - meeting expectations of users, facilitate perceived contact with real or imaginary others

- Social distance - providing mechanisms for communicating with strangers and possible differences between users, varying options for differing levels of expertise, stigma management

- Homophily - facilitating the sharing of common experiences

- Anonymity and privacy - using unidentifiable email addresses and pseudonyms

- Interaction management - providing options for differing degrees of participation, supporting individuals' ability to express themselves.

Walther et al. (2005) argued that not all of these attributes are pertinent to every type of Internet health-support system, but each holds promise for the relative attractiveness and effectiveness of different Internet health information venues. In building an online community, it is important to examine the relevance of each attribute and assess its implementation. For example, Kavanaugh et al. (2005) propose that tools such as 
wikis may be most appropriate for disadvantaged groups, as they are more transparent and have greater usability than web pages that require a full knowledge of HTML. They suggested that web logs (or blogs) are easier to use for facilitating online group interaction and provide more exchange among participants than either listervs or newsgroups. The emergence of innovative tools for non-experts may help to extend the benefits of social participation to a broader population (Kavanaugh et al. 2005).

Finally, designers now routinely incorporate Web 2.0 and associated social networking technologies into the online communities. Boulos and Wheelert's (2007: 2) review of the usefulness of Web 2.0 technologies in online health communities found that they 'represent a quite revolutionary way of managing and repurposing/ remixing online information and knowledge repositories'. However, even though these tools look promising and potentially fit for purpose in many health care applications and scenarios, careful thinking, testing and evaluation research are still needed in order to establish 'best practice models' for leveraging these emerging technologies. If used carefully, it is likely that these new technologies will boost our teaching and learning productivity, foster stronger 'communities of practice', and support continuing medical education/ professional development and patient education (Boulos \& Wheelert 2007).

\section{Table 2: Summary of relevant concepts and evidence from the existing literature}

\begin{tabular}{|c|c|c|c|}
\hline THEME(S) & $\begin{array}{l}\text { KEY CONCEPTS FROM THE } \\
\text { LITERATURE }\end{array}$ & RELEVANT SOURCES & DESIGN IMPLICATIONS \\
\hline $\begin{array}{l}\text { Characteristics of } \\
\text { communities in online and } \\
\text { offline settings }\end{array}$ & $\begin{array}{l}\text { Membership. } \\
\text { Influence. } \\
\text { Integration and fulfilment of } \\
\text { needs. } \\
\text { Shared emotional connection. }\end{array}$ & $\begin{array}{l}\text { McMillan and } \\
\text { Chavis (1986) }\end{array}$ & $\begin{array}{l}\text { Develop boundaries, perceptions of emotional } \\
\text { safety, a sense of belonging, identification } \\
\text { with the collective; opportunities for personal } \\
\text { investment, use of a common symbol system for } \\
\text { communication. } \\
\text { Create rewards and incentives for participation in } \\
\text { the community. }\end{array}$ \\
\hline $\begin{array}{l}\text { Issues in moving offline } \\
\text { communities online } \\
\text { Characteristics of } \\
\text { communities in online and } \\
\text { offline settings }\end{array}$ & $\begin{array}{l}\text { Shared goal, interest, need, } \\
\text { or activity. } \\
\text { Active participation. } \\
\text { Access to shared resources. } \\
\text { Reciprocity of information. } \\
\text { Shared context of social } \\
\text { conventions, language and } \\
\text { protocol. }\end{array}$ & $\begin{array}{l}\text { Whittaker, Issacs } \\
\text { and O'Day (1997) }\end{array}$ & $\begin{array}{l}\text { Support repeated engagement between } \\
\text { participants. } \\
\text { Enable social cues about participant's personality } \\
\text { and characteristics. } \\
\text { Establish rules to govern the community. } \\
\text { Ensure usability in the online environment. }\end{array}$ \\
\hline $\begin{array}{l}\text { Designing online } \\
\text { communities to match } \\
\text { community needs }\end{array}$ & $\begin{array}{l}\text { Designing online communities } \\
\text { to match community needs }\end{array}$ & $\begin{array}{l}\text { Wilson and } \\
\text { Peterson (2002) } \\
\text { Spitulnik (1993) }\end{array}$ & $\begin{array}{l}\text { Situate computing and Internet practices to } \\
\text { compare them with previously existing (before the } \\
\text { Internet) media and communication technologies. } \\
\text { Proposes continuing analyses of power relations, } \\
\text { global capital, and the role of minority groups. }\end{array}$ \\
\hline $\begin{array}{l}\text { Designing online } \\
\text { communities to match } \\
\text { community needs }\end{array}$ & $\begin{array}{l}\text { Relationships are sustained } \\
\text { through a combination } \\
\text { of online and offline } \\
\text { interactions. } \\
\text { Strengthen social identity. }\end{array}$ & $\begin{array}{l}\text { Hampton and } \\
\text { Wellman (2000) } \\
\text { Koh, Kim, Butler } \\
\text { and Bock (2007) }\end{array}$ & $\begin{array}{l}\text { Encourage a mix of communication mediums } \\
\text { online and offline. } \\
\text { Link offline meetings to online activities by } \\
\text { providing access to the online community through } \\
\text { publicly accessible community locations such } \\
\text { as public libraries, municipal buildings or street } \\
\text { kiosks. }\end{array}$ \\
\hline $\begin{array}{l}\text { Issues in moving offline } \\
\text { communities online }\end{array}$ & $\begin{array}{l}\text { Online communities can } \\
\text { strengthen social contacts, } \\
\text { community engagement } \\
\text { and attachment for 'well- } \\
\text { connected' educated people. }\end{array}$ & $\begin{array}{l}\text { Kavanaugh, } \\
\text { Carroll, Rosson, } \\
\text { Zin and Reese } \\
(2005)\end{array}$ & $\begin{array}{l}\text { Need to design communities with non-experts in } \\
\text { mind. }\end{array}$ \\
\hline
\end{tabular}




\begin{tabular}{|c|c|c|c|}
\hline THEME(S) & $\begin{array}{l}\text { KEY CONCEPTS FROM THE } \\
\text { LITERATURE }\end{array}$ & RELEVANT SOURCES & DESIGN IMPLICATIONS \\
\hline $\begin{array}{l}\text { Characteristics of } \\
\text { communities in online and } \\
\text { offline settings } \\
\text { Designing online } \\
\text { communities to match } \\
\text { community needs }\end{array}$ & $\begin{array}{l}\text { Offline community rules and } \\
\text { roles migrate naturally into } \\
\text { the online environment. }\end{array}$ & $\begin{array}{l}\text { Maloney-Krichmar } \\
\text { and Preece (2003) }\end{array}$ & $\begin{array}{l}\text { Consider any changes to the offline community } \\
\text { rules that need to be applied in the online } \\
\text { environment. }\end{array}$ \\
\hline $\begin{array}{l}\text { Designing online } \\
\text { communities to match } \\
\text { community needs }\end{array}$ & $\begin{array}{l}\text { Community-centred design } \\
\text { approach to building online } \\
\text { communities. }\end{array}$ & Preece (2000) & $\begin{array}{l}\text { Work with members of the community from } \\
\text { the beginning to ensure security and trust is } \\
\text { incorporated in the developed community. }\end{array}$ \\
\hline $\begin{array}{l}\text { Characteristics of } \\
\text { communities in online and } \\
\text { offline settings } \\
\text { Issues in moving offline } \\
\text { communities online }\end{array}$ & $\begin{array}{l}\text { New online communities may } \\
\text { strengthen offline geographic } \\
\text { communities. } \\
\text { Developing multiplex } \\
\text { relationships (offline/ } \\
\text { online) can enhance online } \\
\text { engagement. }\end{array}$ & $\begin{array}{l}\text { Nip (2004) } \\
\text { Sessions (2010) }\end{array}$ & $\begin{array}{l}\text { Online communities must bear the same goals and } \\
\text { norms as the offline communities. }\end{array}$ \\
\hline
\end{tabular}

\begin{tabular}{llll}
\hline Designing online & Facilitate social interactions & Kim, Lee and & Gain loyalty of members by encouraging regular \\
communities to match & among members to encourage & Hiemstra (2004) & visits.
\end{tabular}

community needs

\begin{tabular}{|c|c|c|c|}
\hline $\begin{array}{l}\text { Issues in moving offline } \\
\text { communities online } \\
\text { Characteristics of } \\
\text { communities in online and } \\
\text { offline settings }\end{array}$ & $\begin{array}{l}\text { A. Social presence. } \\
\text { B. Motivation. } \\
\text { C. Technology. }\end{array}$ & $\begin{array}{l}\text { Koh, Kim, Butler } \\
\text { and Bock (2007) }\end{array}$ & $\begin{array}{l}\text { A. Create awareness of other people through } \\
\text { graphical, textual and video interfaces (such as } \\
\text { avatars, graphic images and video chat). } \\
\text { B. Develop effective community leaders who } \\
\text { understand the needs of the community. } \\
\text { C. Provide an adequate communications } \\
\text { infrastructure. }\end{array}$ \\
\hline $\begin{array}{l}\text { Issues in moving offline } \\
\text { communities online } \\
\text { Designing online } \\
\text { communities to match } \\
\text { community needs }\end{array}$ & $\begin{array}{l}\text { Online identity important in } \\
\text { knowledge contributions. }\end{array}$ & $\begin{array}{l}\text { Ma and Agarwal } \\
(2007) \\
\text { Koh, Kim, Butler } \\
\text { and Bock (2007) }\end{array}$ & $\begin{array}{l}\text { Provide a rating system and include user profiles. } \\
\text { Collect, display and update content regularly. } \\
\text { Provide a peer evaluation system. } \\
\text { Provide reward systems for valuable postings. }\end{array}$ \\
\hline $\begin{array}{l}\text { Issues in moving offline } \\
\text { communities online } \\
\text { Designing online } \\
\text { communities to match } \\
\text { community needs }\end{array}$ & $\begin{array}{l}\text { Attention to the IT artefact } \\
\text { - the application of IT to } \\
\text { enable/ support some task(s) } \\
\text { embedded with a structure(s) } \\
\text { that itself is embedded } \\
\text { within a context(s). }\end{array}$ & $\begin{array}{l}\text { Matook and } \\
\text { Brown (2008) } \\
\text { Benbasat and } \\
\text { Zmud (2003) } \\
\text { Preece (2000) }\end{array}$ & $\begin{array}{l}\text { Conduct a full investigation of the community's } \\
\text { needs and users tasks to ensure good usability and } \\
\text { sociability. }\end{array}$ \\
\hline $\begin{array}{l}\text { Designing online } \\
\text { communities to match } \\
\text { community needs }\end{array}$ & $\begin{array}{l}\text { Determinants of } \\
\text { sustainability } \\
\text { Perceived usefulness, } \\
\text { perceived ease of use, offline } \\
\text { activities. } \\
\text { Usability and service quality. } \\
\text { Information quality, system } \\
\text { quality, service quality. }\end{array}$ & $\begin{array}{l}\text { Lin (2007) } \\
\text { Preece (2001) } \\
\text { DeLone and } \\
\text { McLean (1992, } \\
\text { 2003) }\end{array}$ & Ensure information systems quality. \\
\hline $\begin{array}{l}\text { Designing online } \\
\text { communities to match } \\
\text { community needs } \\
\text { Characteristics of } \\
\text { communities in online and } \\
\text { offline settings }\end{array}$ & $\begin{array}{l}\text { Encourage collaborative work } \\
\text { in the online community. }\end{array}$ & $\begin{array}{l}\text { Boyer, Maher and } \\
\text { Kirkman (2006) }\end{array}$ & $\begin{array}{l}\text { Inclusion of a group learning contract. } \\
\text { Create a role/ s for an Instructor/ facilitator. }\end{array}$ \\
\hline
\end{tabular}




\begin{tabular}{|c|c|c|c|}
\hline THEME(S) & $\begin{array}{l}\text { KEY CONCEPTS FROM THE } \\
\text { LITERATURE }\end{array}$ & RELEVANT SOURCES & DESIGN IMPLICATIONS \\
\hline $\begin{array}{l}\text { Designing online } \\
\text { communities to match } \\
\text { community needs }\end{array}$ & $\begin{array}{l}\text { Attributes that encourage } \\
\text { success } \\
\text { Interactivity. } \\
\text { Presence. } \\
\text { Social network attributes } \\
\text { (expertise and distance). } \\
\text { Homophily. } \\
\text { Anonymity. } \\
\text { Interaction management. }\end{array}$ & $\begin{array}{l}\text { Boulos and } \\
\text { Wheelert (2007) }\end{array}$ & $\begin{array}{l}\text { Consider building elements of interactivity, } \\
\text { presence, social network attributes (expertise and } \\
\text { distance), homophily, anonymity, and interaction } \\
\text { management into the online community. }\end{array}$ \\
\hline $\begin{array}{l}\text { Designing online } \\
\text { communities to match } \\
\text { community needs }\end{array}$ & $\begin{array}{l}\text { Interventions can be directed } \\
\text { at different levels in the } \\
\text { community. }\end{array}$ & Larson (2007) & $\begin{array}{l}\text { Consider the stakeholder groups involved and } \\
\text { the goals of each group in participating in } \\
\text { the community. Interventions can be directed } \\
\text { at individuals living in the community, at } \\
\text { relationships between those individuals or with } \\
\text { service providers. }\end{array}$ \\
\hline
\end{tabular}

\section{Discussion}

The major limitation of our literature review relates to the lack of specific literature and evidence about the link between offline and online communities. Despite this limitation we have identified some maj or characteristics of multiple, online, and offline communities that will provide pathways for future development. We argue that the concept of 'multiplex' communities in particular is highly relevant to complex health promotion initiatives where collaborating organisations and individuals are geographically dispersed or separated by organisational, disciplinary, and sectoral boundaries.

McMillan and Chavis' (1986) characterisation of communities is a useful one when considering how the elements of a community are manifested in an online environment. For instance, a strong membership base is important and membership is sustained through creating feelings of loyalty and commitment to the community. This loyalty is then linked to influence, in which members are encouraged by their peers (other members) to actively participate in the community on a regular basis. This increases a member's perceived usefulness and sense of belonging in the community. Once members feel that their own needs are being met, they are more likely to integrate within the day-to-day activities of the community, because they feel a sense of belonging. This sense of belonging, in turn, creates a shared emotional connection, which is strengthened through ongoing, shared experiences. Embedding these characteristics within an online community is considered a vital element of success. These characteristics are particularly relevant to complex e-health promotion initiatives that seek to promote place-based collaboration, learning, and/ or change.

Our review of the literature has provided ample evidence that 'multiplex' (Session 2010) community relationships and interactions that cross both online and of fline settings can produce significant benefits including: stronger and sustained community ties and attachment; enhanced engagement in online settings; shared governance that extends across both online and offline settings; and enhanced social presence within online engagements. The two main limitations of blended online and of fline engagement appear to be that: (a) those who are already well-educated and connected will be more inclined to connect in sustained ways with others online than those who are less well educated, less extroverted, and who experience existing social isolation; and (b) groups of participants who do not connect online can separate from the main group and re-form as sub-communities in offline settings which may weaken the value of the online setting. Therefore, design strategies that appease non-experts and that encourage multiplex relationships can help to improve the success of online communities.

In implementing a place-based approach to e-health, Larson (2007) proposed that online interventions can be directed at different levels within the community: the people living in the community, relationships between people living in the community and service providers, or improving the physical infrastructure of an area. However, whatever level is selected, she suggested a shift away from limited physical interventions to a more integrated approach. This integration can be achieved through a 
multiplex community. Overall, the key findings of her extensive review highlighted several factors that are associated with positive improvements in health and the social determinants of health: integrated and holistic approaches; interventions that are fully implemented without premature discontinuation; use of community engagement, participation, and ownership; and a focus on long term and sustainable benefits. The importance of these positive improvements should not be understated.

Finally, it is worth stating the obvious point that online communities will only continue to exist if people visit them regularly and actively participate. So it is essential that once people do visit, communities continue to facilitate social interactions among members, with a desirable outcome of creating loyalty and commitment among community members (Kim, Lee \& Hiemstra 2004).

\section{Conclusion}

By drawing on related literature, we identified the following three broad areas of relevance to the creation of multiplex communities: (i) community characteristics; (ii) issues in moving of fline communities online; and (iii) designing online communities to match community needs. Our conclusions in these three areas will be of interest to those who seek to: (a) design and implement holistic e-health promotion infrastructures and activities; (b) develop supportive online structures and processes for existing complex networks and partnerships; and (c) develop a broader conception of online health promotion than current education and individual behaviour-oriented approaches.

Both our own experience leading knowledge sharing across complex health promotion initiatives over the past six years and recommendations from the current literature indicate that complex health promotion as it is outlined in the Ottawa Charter (WHO 1986) requires fluent, ongoing collaboration and knowledge sharing between participants, particularly within shared geographical areas (Baum 2008; Byron 2010). We argue that existing health promotion initiatives can hence benefit from online platforms that promote community building and knowledge sharing across the organisations and districts that are the focus of investment and broader health promotion networks. Following Sessions (2010), we argue that online e-health promotion settings and communities can successfully integrate with existing offline settings and communities to form 'multiplex' communities.

\section{References}

Astbrink, G. and Beekhuyzen, J. (2003). Synergies of universal design and user-centred design. Proceedings of the International Conference on Human Computer Interaction $(\mathrm{HCl})$, Crete, Greece.

Baum, S. (2008). Suburban scars: Australian cities and socio-economic deprivation. Urban Research Program, Research Paper 15, Griffith University, Brisbane, Australia.

Beekhuyzen, J. and von Hellens, L. (2009). Reciprocity and sharing in an underground file sharing community. Australasian Conference on Information Systems, Monash University, Melbourne, Australia.

Beekhuyzen, J., von Hellens, L. and Nielsen, S. (2011). Underground online music communities: exploring rules for membership. Online Information Review 25(5): 699-715.

Benbasat, I. and Zmud, R. (2003). The identity crisis within the IS discipline: defining and communicating the discipline's core properties. Management Information Systems Quarterly 27(2): 183-194.

Booth, A., Papaioannou, D. and Sutton, A. (2012). Systematic approaches to a successful literature review. London, SAGE.

Boulos, M.N.K. and Wheelert, S. (2007). The emerging Web 2.0 social software: an enabling suite of sociable technologies in health and health care education. Health Information and Libraries J ournal 24(1): $2-23$

Boyer, N., Maher, P. and Kirkman, S. (2006). Transformative learning in online settings: the use of selfdirection, metacognition, and collaborative learning. J ournal of Transformative Education 4(4): 335-360.

Brown, J., Broderick, A.J . and Lee, N. (2007). Word of mouth communication within online communities: conceptualizing the online social network. J ournal of Interactive Marketing 21(3): 2-20.

Buhler, C. (2000). Empowered participation of users with disabilities in R\&D projects. International J ournal of Human-Computer Studies 55(4): 645-659.

Byron, I. (2010). Placed-based approaches to addressing disadvantage: linking science and policy. Family Matters 84(Spring 2010): 20-27. 
DeLone, W. H. and McLean, E.R. (1992). Information systems success: the quest for the dependent variable. Information Systems Research 3(1): 60-95.

DeLone, W.H. and McLean, E.R. (2003). The DeLone and McLean model of information systems success: a ten-year update. J ournal of Management Information Systems 19(4): 9-30.

Evers, K. (2006) e-Health promotion: the use of the Internet for health promotion. American J ournal of Health Promotion 20(4): suppl 1-7, iii.

Fry, J.P. and Neff, R.A. (2009). Periodic prompts and reminders in health promotion and health behavior interventions: systematic review. J ournal of Medical Internet Research 11(2): e16.

Hampton, K. N. and Wellman, B. (2000). Examining community in the digital neighbourhood: early results from Canada's wired suburb. In Digital Cities, LNCS 1765. T. Ishida \& K. Isbister (Eds), Berlin, Heidelberg, Springer-Verlag: 194-208.

Hardiker, N.R. and Grant, M.J . (2011). Factors that influence public engagement with e-Health: a literature review. International J ournal of Medical Informatics 80: 1-12.

Kavanaugh, A., Carroll, J.M., Rosson, M. B., Zin, T.T. and Reese, D.D. (2005). Community networks: where offline communities meet online. J ournal of Computer-Mediated Communication 10(4): Available at: http:// j cmc. indiana. edu/ vol10/ issue4/ kavanaugh. html (accessed 26 February, 2013).

Kim, W.G., Lee, C. and Hiemstra, S.J . (2004). Effects of an online virtual community on customer loyalty and travel product purchases. Tourism Management 25(2): 343-355.

Koh, J., Kim, T-G., Butler, B. and Bock, G-W. (2007). Encouraging participation in virtual communities. Communications of the ACM 50(2): 69-73.

Larson, K. (2007). The health impacts of place-based interventions in areas of concentrated disadvantaged: a review of the literature. Liverpool, New South Wales, Sydney South West Area Health Service.

Lin, H-F. (2007). The role of online and offline features in sustaining virtual communities: an empirical study. Internet Research 17(2): 119-138.

Ma, M. and Agarwal, R. (200). Through a glass darkly: information technology design, identity verification, and knowledge contribution in online communities. Information Systems Research. 18(1): 42-67.

Maloney-Krichmar, D. and Preece, J. (2003). An ethnographic study of an online health support community. The 15th Annual Conference on Ethnographic and Qualitative Research in Education. Duquesne University, Pittsburg, Pennsylvania.

Mao, J-Y., Vredenburg, K., Smith, P.W. and Carey, T. (2005). The state of user-centred design practice. Communications of the ACM 48(3): 105-109.

Matook, S. and Brown, S. A. (2008). Conceptualizing the IT artifact for MIS research. Proceedings of the 24th International Conference on Information Systems ICIS 2008, Association for Information Systems, Paris, France.

McMillan, D.W. and Chavis, D.M. (1986). Sense of community: a definition and theory J ournal of Community Psychology 14(1): 6-23.

Nip, J. (2004). The relationship between online and offline communities: the case of the queer sisters. Media, Culture and Society 26(3): 409-428.

Preece, J. (2000). Online communities: designing usability, supporting sociability. Chichester, J ohn Wiley $\&$ Sons Ltd.

Preece, J. (2001). Sociability and usability in online communities: determining and measuring success. Behaviour and Information Technology. 20(5): 347-356.

Preece, J., Abras, C. and Maloney-Krichmar, D. (2004). Designing and evaluating online communities: research speaks to emerging practice. International J ournal of Web Based Communities 1(1): 2-18.

Ryman, S., Burrell, L., Hardham, G., Richardson, B. and Ross, J. (2009). Creating and sustaining online learning communities: designing for transformative learning. International J ournal of Pedagogies and Learning 5(3): 32-45.

Sessions, L. (2010). How offline gatherings affect online communities. Information, Communication \& Society 13(3): 375-395.

Skinner, H.A., Maley, O. and Norman, C.D. (2006). Developing internet-based e-health promotion programs: the Spiral Technology Action Research (STAR) model. Health Promotion Practice 7(4): 406417.

Spitulnik, D. (1993). Anthropology and mass media. Annual Review of Anthropology 22(1): 293-315.

Vredenburg, K., Isensee, S. and Righi, C. (2002). User-centred design: an integrated approach. New J ersey, Prentice Hall.

Walther, J.B., Pingree, S., Hawkins, R.P. and Buller, D.B. (2005). Attributes of interactive online health information systems. J ournal of Medical Internet Research 7(3): 33.

Whittaker, S., Isaacs, E. and O'Day, V. (1997). Widening the net. ACM SIGCHI Bulletin 29(3): 27-30.

Wilson, S.M. and Peterson, L.C. (2002). The anthropology of online communities. Annual Review of Anthropology 31(1): 449-467.

World Health Organization (1986). The Ottawa Charter for Health Promotion. Geneva, WHO.

World Health Organization (1997). The J akarta Declaration. Geneva, WHO. 
Corresponding author:

Naomi Sunderland, PhD

School of Human Services and Social Work, Griffith Health Institute

Griffith University

Meadowbrook QLD 4131

AUSTRALIA

Tel: + 61733821113

email: n.sunderland@griffith.edu.au

J enine Beekhuyzen

School of Human Services and Social Work, Griffith Health Institute, Griffith University (Australia)

Elizabeth Kendall PhD

Professor, School of Human Services and Social Work, Griffith Health Institute, Griffith University (Australia)

\section{Malcolm Wolski}

Scholarly Information \& Research, Griffith University (Australia) 